DOI: https://doi.org/10.18371/fp.4(44).2021.124132

УДК 336.71

\title{
ФІНАНСОВИЙ КОНСАЛТИНГ З УПРАВЛІННЯ ПЕРСОНАЛЬНИМИ ФІНАНСАМИ КЛІЄНТІВ ЯК ЧИННИК ЗБІЛЬШЕННЯ ПРОДНАВАНТАЖЕННЯ У КЛІЄНТІВ БАНКУ
}

\author{
КОЛССНІКОВА Лариса Леонтіївна \\ аспірантка, \\ Університет банківської справи \\ ORCID ID: https://orcid.org/0000-0001-8977-2258
}

\begin{abstract}
Анноватція. У статті проведено дослідження сутності поняття «фінансовий консалтинг». Запропонована методологія використання фінансового консалтингу 3 метою збільшення клієнтського попиту та досвіду при користуванні комплексом банківських та фінансових продуктів і сервісів, збільшення продуктового навантаження на клієнта та підвищення технологічного рівня використання дистаниійних форматів обслуговування на основі впровадження функціоналу фінансового консалтингу від банківського співробітника.

Розглянуто практичні аспекти застосування фінансового консалтингу при управлінні персональними фінансами клієнтів банку для формування комплексної продуктовосервісної пропозичіiі.

Ключові слова: фінансовий консалтинг, банк, персональні фінанси, управління взаємовідносинами з клієнтами, персональний менеджер, діджиталізачія, продуктове навантаження

(проднавантаження).
\end{abstract}

Постановка проблеми. Ефективність роботи будь-якого банку багато в чому залежить від можливостей щодо залучення грошових коштів, їх розміщення, надання послуг клієнтам. Ці можливості, у свою чергу, визначаються галузевою спрямованістю операцій, обраним клієнтським сегмен-
Аннотация. $B$ cmaтье проведено исследование сущности понятия «финансовый консалтинг». Предложена методология использования финансового консалтинга с иелью увеличения клиентского спроса и клиентского опыта пользования комплексом банковских $и$ финансовых продуктов и сервисов, увеличения продуктовой нагрузки на клиента и повышения технологического уровня пользования дистанционными форматами обслуживания на основе запуска функционала финансового консалтинга от банковского менеджера.

Рассмотрень практические аспекты применения финансового консалтинга при управлении персональными финансами клиентов банка для формирования комплексного продуктово-сервисного предложения.

Ключевые слова: финансовый консалтинг, банк, персональные финансы, управление взаимоотношениями с клиентами, персональный менеджер, диджитализачия, продуктовая нагрузка (проднагрузка).

том, фазою економічного циклу та прийнятою банком моделлю ведення бізнесу.

Також істотний вплив на ефективність банківського бізнесу чинить здатність банку впроваджувати сучасні технології зі спрощення та прискорення проведення внутрішньобанківських 
процедур, здешевлення операцій, забезпечення їх захисту від внутрішніх та зовнішніх посягань на безпеку даних банку та клієнтів, доступу клієнтів до банківських продуктів та послуг, а останнім часом - і надання клієнтам послуг 3 фінансового консалтингу 3 метою задоволення реальних потреб на банківські продукти та послуги.

На даний час фінансовий консалтинг у банку є надзвичайно важливим елементом ринкової інфраструктури, що пов язано з інтеграцією банківського бізнесу з іншими видами бізнесу.

Аналіз останніх досліджень і публікацій. Проблемам розвитку консалтингу присвячені праці таких науковців як М.С. Іванової, Т.Г. Решетняк, Н.В. Дроздової, С.С. Ніколенка, М. Кубр, Е. Бейч, П. Блок та інші.

Виокремлення невирішених раніше частин загальної проблеми. Незважаючи на наявні наукові праці у сфері консалтингу, у сучасних наукових роботах досі грунтовно не реалізовані дослідження фінансового консалтингу 3 управління коштами населення у забезпеченні фінансового результату банку.

Метою статті $\epsilon$ визначення фінансового консалтингу з управління персональними коштами клієнтів як важливого чинника у збільшенні продуктового навантаження у клієнтів банку для забезпечення фінансового результату банку, а також обгрунтування методики продажу банківських продуктів та послуг на основі фінансового консалтингу.

Виклад основного матеріалу дослідження. Необхідно зазначити, що у праці «Керівництво зі статистики міжнародної торгівлі послугами», яка розроблена спільно шістьма організаціями $(\mathrm{OOH}$, Європейська Комісія,
МВФ, ОЕСР, ЮНКТАД і СОР), серед банківських послуг виділено консультаційні послуги [1]. Відповідно до ч.6 ст.47 Закону України «Про банки і банківську діяльність» виокремлено «надання консультаційних та інформаційних послуг щодо банківських та інших фінансових послуг» [2].

Незважаючи на те, що банк $є$ фінансовою установою, С. Глібко стверджує, що банк може надавати консалтингові послуги [3].

Зауважимо, що банки можуть консультувати клієнтів 3 питань, що стосуються і не належать до банківської діяльності. Зокрема, консалтингові послуги банків можна поділити на послуги загального характеру та специфічні послуги [4]. Послуги загального характеру передбачають консалтинг клієнтів у процесі надання банківських послуг (депозитних, кредитних тощо) через персонального менеджеpa, співробітників банку, офіційного веб-сайту банку. Наприклад, до них належать консультації банку про котирування валют, порядок відкриття та ведення банківських рахунків, операції з цінними паперами та іноземною валютою, процентні ставки за депозитами, кредитами тощо. За результатами надання консультаційних послуг загального характеру банки сприяють підвищенню фінансової грамотності клієнтів, лояльності клієнтів, обсягів продажу банківських продуктів та послуг. Специфічні консалтингові послуги банку передбачають надання відповідних послуг під запит клієнта банку (наприклад, вибір стратегії інвестування на ринку цінних паперів) на підставі договірних зобов язань між банком та клієнтом банку.

Приведемо приклад актуальності попиту на фінансовий консалтинг у 
банківській індустрії. Так, у вересні 2020 року АТ «Комерційний індустріальний банк» та польська «ЕКСІ Консалтинг» уклали міжнародну угоду для підтримки малого та середнього бізнесу [5]. Зокрема, угодою передбачено, що клієнти банку отримають консалтингові послуги від банківпартнерів «ЕКСІ Консалтинг» 3 питань пошуку оптимальних кредитних пропозицій, підготовки повної проєктної документації та необхідних документів для отримання фінансування.

У науковій літературі визначення поняття «фінансовий консалтинг» розглядається у різних аспектах: як сукупність заходів, спрямованих на підвищення ефективності фінансового управління 3 урахуванням використання всіх фінансових ресурсів організації клієнта [6]; процес взаємодії консультанта та клієнта для передачі інформації з метою вирішення фінансових проблем клієнта [7]; надання послуг юридичним та фізичним особам 3 метою інвестицій та управління персональними фінансами [4].

В умовах розвитку цифрової економіки та діджиталізації діяльності банків змінюється парадигма взаємодії співробітника 3 клієнтом банку. На думку Б. Кінга, найважливіші зміни для банків будуть пов язані з трансформацією консалтингових послуг [8]. На даний час фінансові консультації це особиста взаємодія співробітника банку 3 клієнтом, але у майбутньому консультації у реальному часі трансформуються та стануть переважно автоматизованими на основі штучного інтелекту. Вивчаючи поведінку клієнтів банку, оцінюючи ризики та визначаючи оптимальні засоби для досягнення фінансових цілей клієнта, система навчиться швидко реагувати на зміну контексту. Зокрема, штучний інтелект $є$ передумовою надання нового формату фінансового консалтингу у банках, який буде здійснюватися за допомогою технологічних засобів 3 урахуванням поведінки клієнта банку.

Пандемія COVID-19 у 2020-2021 pp. викликала кардинальні зміни для банківської сфери у частині розвитку технологій віддаленого онлайн управління рахунками клієнтів-фізичних осіб, розробки нових сервісів, банківських продуктів 3 подальшим замовленням ïх у дистанційному режимі. В той же час, на жаль, рівень фінансової культури та технологічної грамотності населення не зростає такими ж швидкими та сталими темпами.

Необхідно зазначити, що використання банками новітніх цифрових каналів та телекомунікаційних повідомлень 3 метою інформування клієнтів банків щодо нових банківських продуктів та послуг не забезпечують їх подальше використання. Зокрема, банки, витрачаючи кошти на телекомунікаційні маркетингові кампанії (sms, push), не отримують бажаного високого рівня успішності (response rate) через вплив багатьох чинників.

Одним з чинників, що впливають на рівень успішності (response rate) $є$ piвень фінансової інклюзії населення України. Згідно з оприлюдненим звітом «Фінансова грамотність, фінансова інклюзія та фінансовий добробут в Україні у 2021 році» проєкту USAID «Трансформація фінансового сектору» у співпраці з Національним банком України, проведеного за методологією Міжнародної мережі фінансової освіти Організації економічного співробітництва та розвитку (ОЕСР), за останні три роки індекс фінансової грамотності українців зріс до 12,3 балів порівня- 
но 3 11,6 балів у 2018 році [9]. Також ненадання професійних консультацій клієнтам банку щодо особливостей використання банківського продукту або сервісу призводить до появи збитків банку внаслідок відсутності конвертації інформаційних банківських пропозицій у купівлю та початок використання фінансового сервісу чи продукту.

Сучасний тренд використання банками роботизованих інформаторів (чат-ботів, IVR (Interactive Voice Response), голосових роботів) 3 метою економії витрат на кваліфікований персонал колл-центрів дозволяє збільшити пропускну здатність запитів клієнтів, але на жаль, на даний час відсутні офіційні дані щодо втрачених вхідних запитів клієнтів, які не ідентифікували свій запит згідно з озвученим 3 IVR меню.

На практиці, вітчизняні банки вимірюють рівень якості обслуговування клієнтів - показник NPS (Net Promote Score), але на даний час немає даних щодо вимірювання рівня задоволення клієнтів при обслуговуванні клієнтів виключно за допомогою роботизованих систем чи при використанні виключно технічних форматів комунікації банку з клієнтами. Такі автоматизовані формати обслуговування виключають 3 процесу людинупрацівника банку, якому можна пояснити чи конкретизувати відповідні проблеми чи питання від клієнта.

Перш за все, варто зауважити, що більшість клієнтських кейсів не мають можливості бути ідентифікованими технічними засобами в силу неформалізованості індивідуальних запитів клієнта i, відповідно, такі запити втрачаються. Зокрема, це призводить до появи клієнтів, які незадоволені бан- ківським обслуговуванням та до подальшої зміни бренду обслуговуючого Банку. 3 метою утримання клієнтів банки почали приділяти увагу покращенню сервісу і підвищенню лояльності клієнтів, для чого проводять опитування клієнтів 3 метою дізнатися про слабкі та сильні сторони банку 3 позиції клієнтів[10].

Щодо «людяних», але стандартизованих за певними ознаками масових маркетингових CRM кампаній від банків 3 обдзвонами клієнтської бази співробітниками банку, які використовують технічні параметри «типового клієнта» як цільової аудиторії (ЦА) для пропозиції конкретного банківського продукту, то вони стикаються 3 низьким рівнем (максимум 1-3\%) успішності, тому що клієнти-фізичні особи, особливо у сегментах «Заможний» (Affluent) сприймають такі дзвінки як спам чи грубе нав'язування тієї чи іншої послуги, яку вони вважають неактуальною у момент дзвінка [11, 12].

На даний час можна зазначити, що актуальною проблемою стала деперсоналізація просування та продажу масових банківських продуктів та послуг для відібраної масової цільової аудиторії, як окремої сутності без створення унікальної пропозиції для кожного клієнта банку.

Використання програмних продуктів CRM та штучного інтелекту, який аналізує банківську поведінку клієнта на основі звітів про рух коштів клієнта дає можливість банкам покращити точність та персоніфікацію пропозицій банківських продуктів та послуг для клієнтів. 3 іншого боку, на практиці клієнти банку негативно реагують на надлишкову інформацію про банківські продукти та послуги, що призво- 
дить до інформаційного перевантаження та впливає на їхнє рішення про купівлю банківських продуктів та послуг. Також пандемія COVD-19 поглибила проблему деперсоналізації через ліміти та заборони карантинних обмежень на персональну комунікацію у форматі «продавець-клієнт».

Пропонуємо розглянути методику на основі нової функціональної ролі банківського співробітника 3 продажу банківських продуктів та послуг, яка базується на певних організаційних та процесних ініціативах (рис.1), та складається з таких етапів:

1) сегментування клієнтської бази за фінансовими критеріями;

2) портфелювання клієнтів за персональним менеджером-фінансовим консультантом;

3) нормування навантаження або кількості клієнтів в портфелі персонального менеджера (далі - ПМ);

4) розробка та впровадження показника ефективності застосування комплексного фінансового консультування - параметра «проднавантаження» клієнта, який враховує кількість активних продуктів та сервісів банку, якими клієнт користується на постійній основі (щомісяця). Кожний продукт чи сервіс має диференційний коефіцієнт «корисності» 3 погляду врахування в параметр проднавантаження (наприклад, наявність депозитів у різних валютах у клієнта має коефіцієнт $\mathrm{k}=2$, а факт використання платіжної картки при оплаті у торговельній мережі $\mathrm{k}=$ 0.5 і т.п.);

5) організація та впровадження цифрових каналів для комунікації 3 персональним менеджером (використання месенджерів для персоніфікованих повідомлень від ПМ);
6) організація процесу попереднього запису до ПМ відповідно до його робочого календаря через дистанційні канали (сайт/чат бот/кол-центр);

7) використання спеціальних структурованих CRM інструментів для фіксації та відображення активних фінансових продуктів та сервісів клієнта 3 портфелю у форматі, зручному для використання ПМ при комплексному фінансовому консалтингу завдяки візуалізації наявних продуктів чи сервісів та фокус на інших флагманських продуктах, які можуть зацікавити клієнта згідно з його стилем життя та потребами у фінансових продуктах і технологіях;

8) використання стандартизованого сценарію комплексного фінансового консалтингу від ПМ, який охоплює головні альтернативні банківські продукти чи сервіси, які згруповані у 4 блоки на основі потреб у клієнтському сервісі, а саме: 1. Управління активами клієнта; 2. Кредитування (фінансування) від банку; 3.Страхування та захист; 4. Цифрові сервіси (або спеціальні програми лояльності для клієнтів чи інші сучасні та актуальні послуги від партнерів банку).

Таким чином, методика пропонує змінити парадигму банківського обслуговування клієнта 3 потоку (непередбачувані запити) на комплексний фінансовий консалтинг за спектром основних банківських послуг від портфельного ПМ, який працює на основі KYC (know your client) та спеціальних CRM інструментів, які персоніфікують клієнта 3 метою побудови довгострокових партнерських відносин $з$ клієнтами банку. 


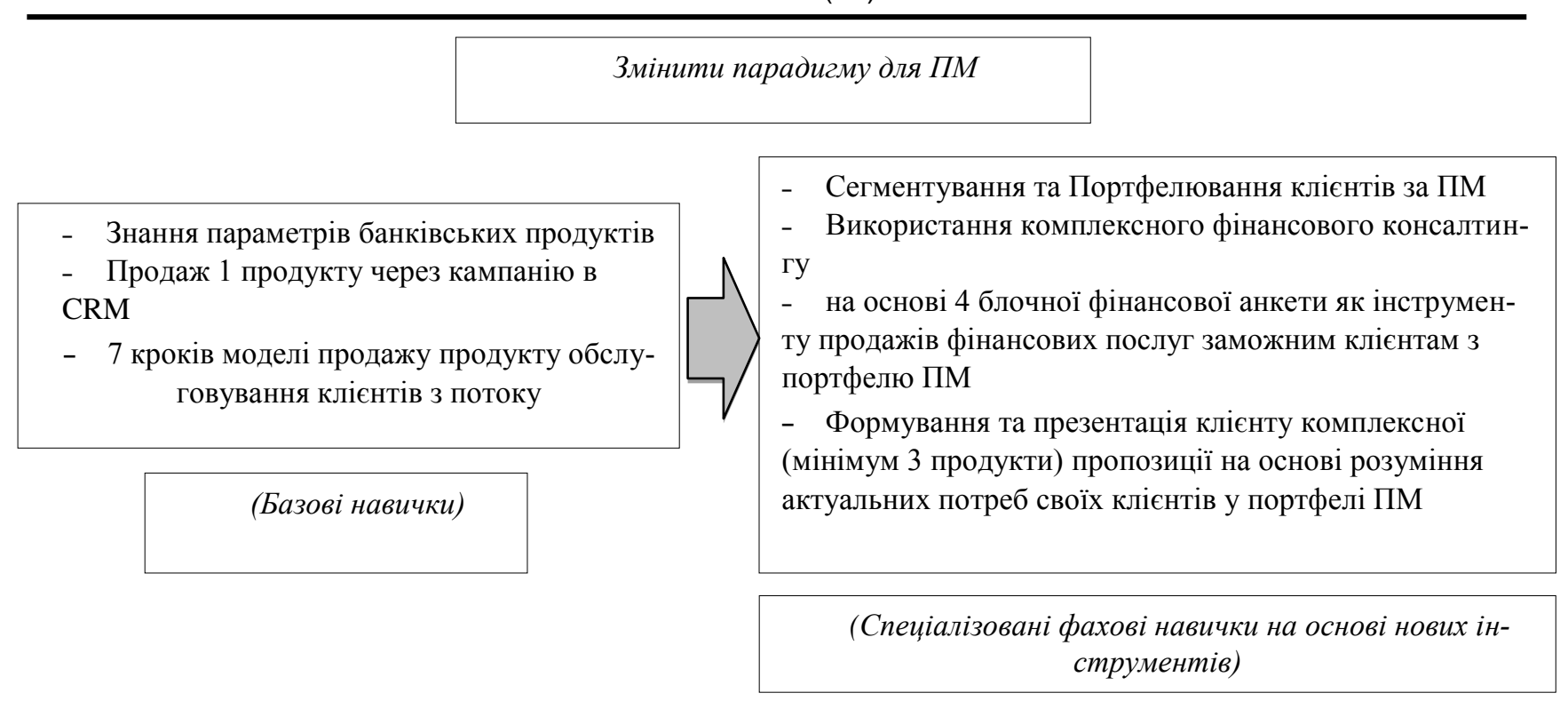

Рис.1 Основи фінансового консалтингу для ПМ: «Флагманські продукти для Affluent клієнтів з використанням комплексної 4 блочної фінансової анкети» Джерело: сформовано автором

Пілотний проект, який проходив у жовтні 2021 р., до якого було залучено 1867 заможних клієнтів АТ «Ощадбанк», з якими ПМ провели зустріч та комплексну фінансову консультацію 3 метою інформування клієнтів щодо актуальних флагманських продуктів та сервісів банку, продемонстрував збільшення значення середнього проднавантаження 3 рівня 3,91 продуктів/сервісів на 1 клієнта пілотної групи до 4,11 за жовтень $(+5,28 \%)$ та до $4,27(+3,73 \%)$ за листопад 2021 року (рис.2). Як бачимо, зафіксовано фактичне зростання параметру проднавантаження у відсотках $+9,20 \%$ у пілотній групі клієнтів протягом 2 місяців після проведення різними персональними менеджерами комплексного фінансового консалтингу клієнтам пілотної групи за спектром банківських та фінансових послуг з використанням 4 блочної фінансової анкети.

Після аналізу динаміки значення проднавантаження, пілотна група була розділена на такі підгрупи за фінальним результатом динаміки значення проднавантаження: зростання проднавантаження, зниження проднавантаження, без змін (рис.3).

Бачимо, що $37 \%$ клієнтів пілотної групи збільшили проднавантаження в середньому на 2,9 балів, що, у свою чергу, свідчить про ефективність комплексного фінансового консалтингу, де клієнт банку підбирає під свої потреби відразу декілька банківських продуктів та послуг. Також 48\% клієнтів пілотної групи не змінили проднавантаження в силу консервативності або обережності при управлінні персональними фінансами, особливо в умовах пандемії COVD-19, не зважаючи на поради фінансового консультанта. 3 іншого боку, 14,5\% клієнтів зменшили проднавантаження через припинення користування відповідними банківськими продуктами та послугами (наприклад, забрали депозит, закрили кредитну картку тощо). 


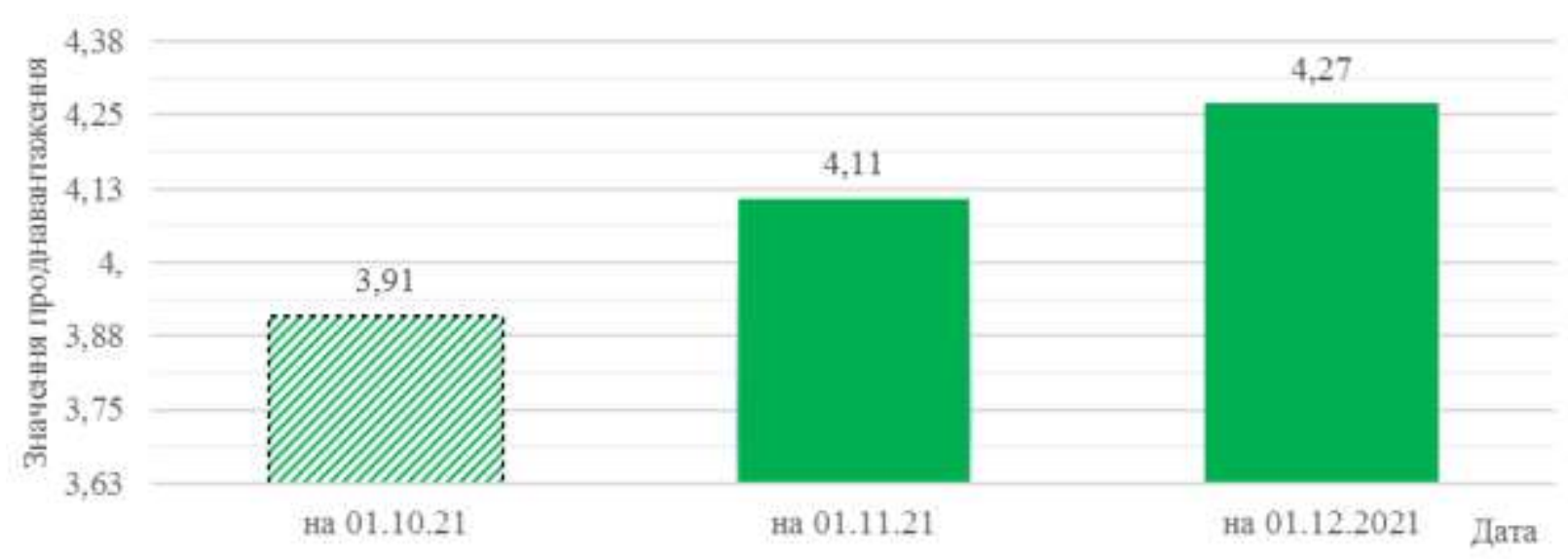

Рис. 2 Середнє проднавантаження за клієнтами в пілотній групі до проведення фінансового консалтингу (на 01.10.2021р.) та після проведення фінансового консалтингу (01.11. 2021 р. - 01.12.2021р.) з використанням 4 блочної фінансової анкети клієнта

Джерело: сформовано автором

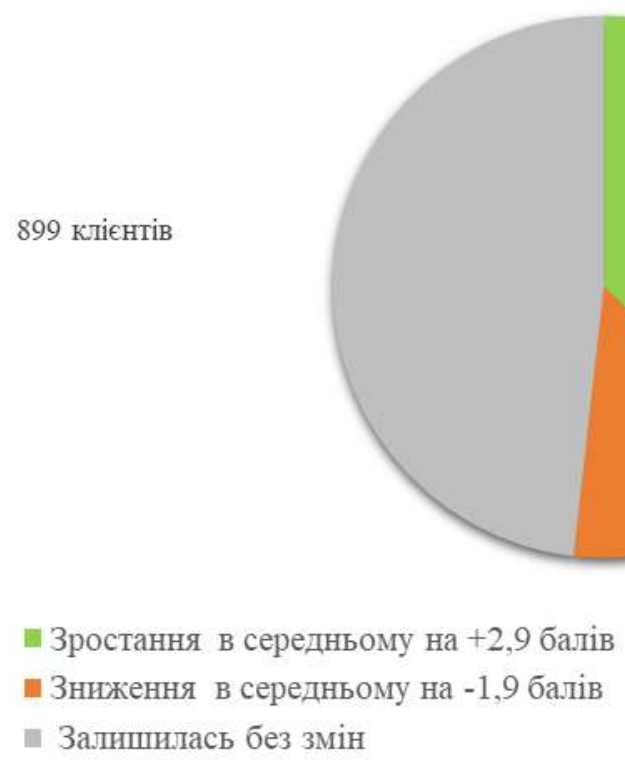

Рис.3 Динаміка значення проднавантаження у пілотній групі Джерело: сформовано автором

Висновки. Встановлено важливість комплексного фінансового консалтингу у діяльності банку при обслуговуванні клієнтів, яке можливо забезпечити за допомогою використання сучасних аналітичних даних у CRM системах про клієнтів, зміни парадигми обслуговування клієнтів за портфельним принципом, а також цифрової трансформації банківських операцій та комунікацій з клієнтами. Зокрема, на динаміку параметру проднавантаження клієнтів продуктами та сервісами банку 3 використанням послуги комплексного фінансового консалтингу впливає рівень кваліфікації та мотивації банківського менеджера, поведінка клієнтів, конкурентоспроможність банківських продуктів та послуг та інші чинники.

Банки, які використовують сучасні інформаційні технології, при цьому не 
зменшують, а трансформують роль банківського співробітника та підвищують його кваліфікацію до формату фінансового консультанта, змінюють методики сервісу клієнтів та здатні врахувати інтереси клієнта, отримують конкурентні переваги, що в ре- зультаті позитивно впливає на фінансовий результат.

Перспективою подальших досліджень у даному напрямі $\epsilon$ оцінка впливу фінансового консалтингу 3 управління коштами населення на фінансовий результат банку.

\section{Список використаної літератури}

1. Manual on Statistics of International Trade in Services (MSITS). Geneva, Luxembourg, New York, Paris, Washington, D.C., 2010. 155 p.

2. Про банки та банківську діяльність: Закон України від 07.12.2000 p. №2121-III. URL: https://zakon.rada.gov.ua/laws/show/2121-14 (дата звернення: 07.12.2021).

3. Глібко С.В. Особливості визначення банківських послуг у законодавстві України Теорія $i$ практика правознавства. 2013. Вип. 2. URL: http://nbuv.gov.ua/UJRN/tipp_2013_2_21 (дата звернення: 07.12.2021).

4. Поліщук С. А., Дубина П.В., Паплик В.В. Консалтинг як нетрадиційна послуга банків. Фінансові дослідження. 2017. № 2 (3). URL: http://nbuv.gov.ua/UJRN/find_2017_2_11 (дата звернення: 07.12.2021).

5. «Комерційний індустріальний банк» та польська «ЕКСI Консалтинг» уклали міжнародну угоду про співпрацю. URL: https://cib.com.ua/uk/about/news/komerciyniy-industrialniy-bank-ta-polska-eksikonsalting-uklali-mizhnarodnu-ugodu-pro-spivpracyu-1 (дата звернення: 07.12.2021).

6. Гернего Ю. О. Перспективи розвитку фінансового консалтингу в Україні. Ефективна економіка. 2019. № 11.2 URL: http://www.economy.nayka.com.ua/?op=1\&z=7387 (дата звернення: 10.12.2021). DOI: $10.32702 / 2307-2105-2019.11 .45$

7. Карпишин Н. І., Жукевич С. М., Фінансове консультування населення: теоретико-організаційні аспекти діяльності. Економічний аналіз: зб. наук. пращь. 2017. Том 27. № 2. С. 91.-97.

8. Brett King. Bank 4.0 : banking everywhere, never at a bank. Singapore: Marshall Cavendish Business, 2018. 308 p.

9. За останні три роки рівень фінансової грамотності українців поліпшився результати дослідження. URL: https://bank.gov.ua/ua/news/all/za-ostanni-tri-rokiriven-finansovoyi-gramotnist-ukrayintsiv--polipshivsya--rezultati-doslidjennya (дата звернення: 10.12.2021).

10. Панченко О.В. Удосконалення маркетингових комунікацій у забезпеченні ефективності діяльності банків в Україні. Вісник Хмельницького національного університету. Серія: «Економічні науки». 2020. №2. С. 7-13. DOI: 10.31891/2307-5740-2020-280-2-1 
11. Girchenko T., Ovsiannikova Y., Girchenko L. CRM System as a Keystone of Successful Business Activity. Knowledge - Economy - Society. Challenges and tools of modern finance and information technology Krakow, Poland. 2017. P. 251-261.

URL: https://cfm.uek.krakow.pl/page/books-4_(дата звернення: 10.12.2021).

12. Колєснікова Л.Л. Фінансовий консалтинг з управління персональними фінансами клієнтів на прикладі практики Ощадбанку. Розвиток банківських систем світу в умовах глобалізаиії фінансових ринків : матеріали доповідей XV Міжнародної наук.-практ. конф. (17 листопада 2021 року, м. Черкаси). Черкаси : ЧННІ Університет банківської справи, 2021. С. 99-102. 